\title{
How an Individual Could Become a Rational Egoist Link Between Ayn Rand and Hayek's Economics, Ethics, and Politics
}

\author{
QIANXUN MA ${ }^{1, a}$ \\ ${ }^{1}$ Chang Zhou No.1 Middle School, ChangZhou, JiangSu213004, China \\ am13915893776@163.com
}

\begin{abstract}
Ayn Rand's opinions in Economics and Politics are highly in accordance with Hayek's since both of them are the strong supporters of capitalism. However, their perspectives differ greatly in Ethics and the regulations of governments: Rand has her own system of standard values; Hayek's thoughts were more indifferent as economists. With the help of their theories, readers might know how to behave properly as the inspired individuals.
\end{abstract}

Keywords: Ayn Rand, Hayek, rational selfishness

\section{INTRODUCTION}

It is reckless to put Ayn Rand and Hayek's names together, not to mention the comparison between their theories. Ayn Rand possessed her own unique school of thought_-Objectivism, or "extreme individualism", as most Chineses readers consider. F.A. Hayek was the economist among the Austrians who was also popular in Chinese academia. From their profiles, we could easily determine that there might be no overlapping areas of their fields. However, the fact is these two philosophers had various notions in common. I mainly put my efforts into investigating Ayn Rand and Hayek's points of view on ethics, morality, and economics, digging up their similarities, differences, and coming up with insufficiency in their theories. I also put my own analysis of scholars' preference in this essay.

\section{RESEARCH QUESTIONS AND INTENTIONS}

By comparing the thoughts of these two philosophers in the field of Economics, Ethics, and Politics, I would like to explore why they advocate for individualism and how people could attain the goal of living a rational selfish way.

In society I used to live in, people hardly talk about or they are prevented from discussing individualism since individualism often closely relates to the adjectives like "selfish", "egoistic", and even "immoral"-these stereotypical words-from most Chinese scholars' perspective. However, researchers should return to the original definitions, regarding what is Collectivism and its counterpart-Individualism. Furthermore, Rand's Objectivism, which emerges from egoism, is worth looking.

\section{LITERATURE REVIEW}

In terms of the Oxford dictionary, selfish means that "devoted to or concerned with one's own advantage or welfare to the exclusion of regard for others." While in the Princeton's WebNet, it explains selfishness as "stinginess resulting from a concern for your own welfare and a disregard of others." Not surprisingly, these definitions all emphasize a excess interest in self and the ignorance of others.

Meanwhile, an altruist is "a perfect example of the selfless man who is a ruthless, unprincipled egotist-in the accepted meaning of the word. A tremendous vanity and greed, which leads him to sacrifice all for the sake of a "brilliant career."' According to Rand, altruism is the exact opposite of egoism - "a selfless concern for others," and "the principle or practice of unselfish concern for or devotion to the welfare of others.

The exact meaning should exist in the dictionary is "concern with one's own interests" which expresses the meaning more neutral, revealing no attitude of whether this word is kind or evil. 
However, In the perspective of Objectivist Ethics, selfishness is a merit.

From psychologists' view, collectivism can be defined as

(1) concern by a person about the effects of actions or decisions on others,

(2) sharing of material benefits,

(3) sharing of nonmaterial resources,

(4) willingness of the person to accept the opinions and views of others,

(5) concern about self-presentation and loss of face,

(6) belief in the correspondence of own outcomes with the outcomes of others,

(7) feeling of involvement in and contribution to the lives of others. [1]

Compared to (1), (4), (5), and (6), (2), (3), and (7) suits the public's perception of a collectivist. In fact, a pure egoist, even the extreme Rand, could care much about others' circumstances and feedback because of the social interactions. In Atlas Shrugged, Rand reflected, "Selfishness does not mean only to do things for one's self. One may do things, affecting others, for his own pleasure and benefit. This is not immoral, but the highest of morality."

Hayek stated, "Centrally planned economy will fail because the individuals task with planning the economy will not have enough information to allocate resources correctly." Hayek had always been a strong opponent of communism and their utopian economics. Similarly, Rand definitely agreed. Rand was born in a middle-class Jewish family in St.Petersburg, Soviet Russia. When she was twelve, the Bolshevik Revolution overturned her hometown and caused her family to flee south, plunging her back to poverty and starvation. It was her hatred of Russian tyranny that formed the basis of her most famous writings. She no longer trusted the planned economy. To some extant, the relationship between Ayn Rand's economic view and the Austrians' is like two peas in a pod. To be more specific, Ayn Rand high recommended the economic writings of the Austrian school since these economist asserted that "leave economics to the United States". At least in so far as regards antitrust, money, and the government.[2]

Ayn Rand and Hayek's explanations could prove how individualism works in economic mechanisms. The ideological impact stems from economics and politics. It is merchandizing, which leads the development of ethics. Both of the philosophers experienced the middle period of the twentieth century in United States. It was the time when individualism found its most ardent champion. Almost every youngster held an Atlas Shrugged on his or her hands; teenagers had started up their rebellion of culture, of social system. After a generation's endeavors, the mature capitalism has been established. $\mathbf{3}^{[}$

It was due to the progress in the public's concept, or individuals have woken up. In terms of philosophers in all fields, individuals have the full control and possession of their mind and body, and rights to live their own lives and to enjoy fruits of their labor. For Rand and Hayek, it is moral to employ individualism and they introduced ethical dimension to the economic activity.

Nonetheless, Hayek is totally different from Rand when considering the government's regulations in business. From Hayek's perspective, governments should make contracts in restraint of trade. As he said, "government should make competition as effective and beneficial as possible and to supplement it where, and only were, it cannot be made effective by markets." Hayek has little confidence in the market could regulate itself appropriately and some people also call him an interventionist. Unfortunately, he is not an interventionist since he wrote "The more the state "plans" the difficult planning becomes for individuals." Admittedly, he is not a big fan of gold, and favors competing private sector currencies; he still advocated for the improvement of capitalism. Unlike what Thoreau demonstrated in Civil Disobedience "The government is best which governs not at all," Hayek proposes that the government should exert as much control as it can over the economy to gain the optimal result.

Nevertheless, contrary to the perspective of Hayek, Rand maintained, "We can never forget the scorn, venom, and ridicule that she heaps upon the anti-dog-eat-dog Rule." Rand strongly recommended the anti-statist nostrums.

The duel between Rand and the Austrians is a duel between objectivism and subjectivism. Randians argue that market prices are objective in the sense that they reflect objective reality. Austrians, argue in contrast that market prices are subjective in the sense that they reflect individual's subjective preferences. Mises wrote, "Value is not intrinsic. It is not in things and conditions but in the valuing subject... There are no such things as absolute values, independent of the subjective preferences of erring men. Judgments of values are the outcome of human arbitrariness. They reflect all the shortcomings and weakness of their authors." Rand explain, "the freemarket value of goods does not necessarily represent their philosophically objective value, but only their socially objective value; the sum of the individual judgements of all the men involved in trade at a given time, the sum of what they valued, each in the context of his own life. This does not mean, however, that the values ruling free market are subjective." ${ }^{\text {" }}$ ] Their attitudes differed greatly on whether it is people who take control of the price on the labels and the free market trading. 
Standing at the front of Objectivism, Rand illustrated that ethical principles were not dependent on the institutional context and reduces all contexts to that of the trader. Her motto for merchandising is "Value for Value." The trader works in his self-interest but only by simultaneously serving the self-interest of the other party or parties to trade. The principle of trade is the only rational ethical principle for all human relationships, personal and ethical, private and public spiritual and material. Love is the ultimate act of the trader, as he or she acquires the happiness that comes from appreciating the values of others and vice versa. Indeed, selfish people usually find it proper to take others into account since personal relationships are indispensable in the progress made by the human beings. Letting people know that they are been aware by others, and they are treated with honesty and sincerity is what people expected and are willing to behave to others. This peaceful exchange of value will not generate quarrels and could ensure the individual's self-interest in the long term.

If we call the Radian scholars reductionist since Rand thought her ethical system should have the universal applicability, then Hayek's thoughts could be concluded as overlapping sub-orders.

According to Hayek, Part of our present difficulty is that we must constantly adjust our lives, our thoughts and our emotions, in order to live simultaneously within different kinds of orders according to different rules... So we learn to live in two sorts of world at once. [5]His proposal was that different ethical principles are necessary in different institutional contexts. In the meantime, Ethics is the last fortress in which human pride must now bow in recognition of its origins. Such an evolutionary theory of molar its is neither instinctual nor a creature of reason.

Hayek proposed that people are able to live in two cosmoses at once, which means that people could be compatible to every situation. As Sartre said, although we do not know why we were born, nor can we choose the environment in which we will grow up. Yet as individuals, we can constantly make choices and take responsibility for each one of them. In reality, we should adjust ourselves to this kind of lifestyle because there are a variety of roles we have to play. Still. This proposal does not mean that we-- human beings-have infinite potentials to be explored or we will not ruin anything up when we are exhausted. At the moment we chose to follow one certain way of thinking or get accustomed to our lives, we then naturally exclude some other possibilities. Hence, none of us could be absolutely objective or comprehend completely for the existence of limitations in horizons.

To the opposite of Hayek's opinion, Rand places her philosophical central emphasis on reason which, she accentuated, as the humans' basic means of survival. She explained, "Human life and human survival depend upon humans being able to exercise their reason."

Meanwhile, she refused to recognize the importance of context and the social consequences of adopting particular ethical codes in order to be more objective. All she would like to do is to examine alone and find what the truth is.

As a matter of fact, the human being's recognition, which Rand employs most often, has its distinctive trait that it is able to entertain in mind without putting the imaginations into practice. Nevertheless, the disadvantage is also obvious. A wide variety of ideas must be entertained to check with the facts and analyze the debate. Even meticulously examining ideas and values does not come out with the right answer of ethics people really needs.

Rand had put all her efforts into find the universal resolutions of every ethical problem. On the contrary to that, Hayek's ethics is more understandable because he accentuated particularly on Function and Social order. For example, from this economist's view, the role of education might be crucial in helping people to understand the function played by each ethical system and thus facilitates the continuation of evolution and growth.

Again, there is a conflict of opinions regarding the family. Rand put forth that families enforce the concept of "duty." Bringing the virtue of selfishness to the forefront has always been her advantage.

Nevertheless, Hayek showed his appreciation to families, which could produce good social outcomes. The key function of a family is that it serves as a cultural institution that rules can be transmitted across generations. Being economic at any time would be the tenet of Hayek.

One notorious joke about Ayn Rand is that, the world's famous individualist died alone. This humor is sarcastic when compared to quote in her Atlas Shrugged, "I swear-by my life and my love of it - that I will never live for the sake of another man, nor ask another man to live for mine." On the other hand, adopting Hayek's way to treat one's own family seems like utilitarianism because he ignored the normal emotional connections between family members.

From comparing these two philosophers, I think researchers should never forget that the reason we study philosophy in the first place is to live a better life. At its birth, philosophy sought to ask questions and understand the world, hoping that the truth would guide people in how to live in situations of illness, hardship, frustration, and other changes and vicissitudes of life.

In addition, therein lies the beauty of philosophy, the fundamental and simple desire to sort out one's outlook on life. No matter how much shackles and restraints are imposed in the real world, in the world of thinking, for 
every individual, everything in the world can be questioned and challenged, and all noble beliefs and ideas can be chosen by an insignificant me, which is so inspiring and free.

The more uncertainty in the world, the more we need to become philosophers of our own lives.

In the year 2020 that just passed, an epidemic changed the way of life for many people. The world is becoming more and more unbalanced, and everyone's life is changing either dramatically or subtly. This is when inner order and balance become especially important. Even though the world is chaotic and unpredictable, we still want to believe that life has a meaning that we can choose for ourselves. After all, in the world of philosophy, not even time and death can disturb the mind.

\section{CONCLUSION}

The question that remains is why Hayek is recognized by most Chinese scholars when he also advocates individualism. It is because Hayek belonged to the Austrian school and his ideas were always traditional which is more likely for Chinese investigators to accept. He never made drastic statements, including condemnations. Instead, he chose to look at things as dialectically as possible. He usually gave some affirmation to a theoretical policy, but quickly dismissing it and providing enough reasons for it. For instance, Hayek proclaimed, "It thus comes about that in practice it is regularly the theoretical collectivist who extols individual reason and demands that all forces of society be made subject to the direction of a single mastermind, while it is the individualist who recognizes the limitations of the powers of individual reason and consequently advocates freedom as a means for the fullest development of the powers of the inter-individual process." After all, Hayek's success could be attributed to the crown effect to some extent.

In contrast to him, Rand was a rule-breaker and her work is tantalizing because of the novel theories came up in her scripts. Nonetheless, Chinese scholars associate with the extremes immediately when they hear that selfishness can be linked to virtue.

From Rand, I learnt that Objectively Self-Interested or the Inspired individualism is to use reason to pursue long-range self-interest for the achievement of personal happiness and fulfillment according to man's nature and needs. We, normal people, could also adopt this principle and live a better life.

I look forward to further exploring the impact of Rand's ethics on people's lives, and bring her work to a wider range of Chinese audience.

\section{REFERENCES}

[1]. Hui CH, Triandis HC. Individualism-Collectivism: A Study of Cross-Cultural Researchers. Journal of Cross-Cultural Psychology. 1986;17(2):225-248. doi:10.1177/0022002186017002006

[2]. Block, Walter. "Ayn Rand and Austrian Economics: Two Peas in a Pod." < $i>$ The Journal of Ayn Rand Studies $</ \mathrm{i}>$ 6, no. 2 (2005): 259-69. Accessed September $11,2021$. http://www.jstor.org/stable/41560283.

[3]. Daniels E. (2011) A Brief History of Individualism in American Though. In: Forsyth D.R., Hoyt C.L. (eds) For the Greater Good of All. Jepson Studies in Leadership. Palgrave Macmillan, New York. https://doi.org/10.1057/9780230116269_5

[4]. The duel between Rand and the Austrians is a duel between objectivism and subjectivism. by Peter T. Calcagno, Joshua C. Hall, Robert A. Lawson, Peter T. Calcagno, Joshua C. Hall, Robert A. Lawson http://citeseerx.ist.psu.edu/viewdoc/summary?doi= 10.1.1.407.9420

[5]. Horwitz, Steven. "Two Worlds at Once: Rand, Hayek, and the Ethics of the Micro- and Macrocosmos." <i>The Journal of Ayn Rand Studies</i> 6, no. 2 (2005): 375-403. Accessed September 11, 2021. http://www.jstor.org/stable/41560288. 